\title{
GROWTH AND SUSTAINABILITY OF SELF HELP GROUPS (SHGS) IN INDIA: A REGIONAL ANALYSIS
}

\author{
Dr Shallu Sehgal ${ }^{1}$ and Nikita Sharma ${ }^{2}$ \\ ${ }^{1}$ Assistant Professor, Department of Economics, University of Jammu, Jammu \&Kashmir \\ ${ }^{2}$ Ph.D Research Scholar, Department of Economics, University of Jammu, Jammu \& Kashmir \\ DOI: 10.46609/IJSSER.2021.v06i07.029 URL: https://doi.org/10.46609/IJSSER.2021.v06i07.029
}

\begin{abstract}
The policy makers of India have laid immense focus on inclusion of unprivileged section of the society placed at the bottom of the pyramid. Credit through microfinance facility has helped severing this section of the society. These efforts were met in 1992 by NABARD initiative of launching Self Help Groups-Bank Linkage programme (SHGs-BLP), thus with a view of greater access of credit to rural areas and an objective of banking with poor. This programme not only served the purpose of financial inclusion for the nation but gave an impetus to empowerment of the women by letting them take benefit of their collective power. This study seeks to highlight the performance of the programme in different regions of the country by taking three important aspects like savings, loan disbursed and loan outstanding. The study considers the period of eleven years, starting from 2010-11 to 2020-21. For this purpose, Mean, Standard Deviation, Coefficient of variation and Compound annual growth are calculated. Further to analyze the statistical significance, Analysis of variance (ANOVA) is calculated. As such it is concluded that the impact of Self Help Group Bank Linkage Programme (SHG-BLP) was different on all the regions of the country, as such showing a positive trend in the progress for the study period as far as savings, loan disbursal as well as loan outstanding is concerned.
\end{abstract}

Keywords: Empowerment, Financial Inclusion, NABARD, Poverty, SHG-BLP.

\section{Introduction}

With a large population of the nation residing in the rural areas of the country signifies the important role rural economy plays for the nation. As such key agenda of the policy makers always revolved around the empowerment aspect for this area. Giving access to financial markets by the rural poor is one such way to empower them. People when get easy access to credit have a greater opportunity to explore their true potential and take benefit of the current situation to improve their income levels as well as their standard of living. Despites so many 


\section{International Journal of Social Science and Economic Research}

ISSN: $2455-8834$

Volume:06, Issue:07 "July 2021"

efforts on the part of both the centre as well as the state governments, it is found that rural sector still could not take benefit of the banking facilities available in the country, since they did not have the required collateral to prove their worth of repaying to the bank and thus are still dependent upon the money lenders to fulfil their credit needs. Moneylenders on the other hand took advantage of their illiteracy and plays with ways until; the farmer is into the vicious circle called the debt trap. This not only exploits the poor financially but gave opportunities to the moneylender to make them slaves for lifetime. The careless attitude of the formal financing agencies towards the poor section of the society has been progressively yielding place to adoption of SHG mode of intervention to fight the scourge of poverty, employment generation and women empowerment(Meena \& Prasad, 2021)

Most of the financial institutions refrain from lending to poor and neglected sections of the society keeping in view the risk of low returns from them. As such policy makers works hard to find different finance delivery methods which could suit the Indian rural conditions and would give boost to financial inclusion in India. The concept of microfinance was being popularized in Bangladesh by Professor Mohammad Yunus. Microfinance really took off in the 1970's with the activities of the Grameen Bank, Bangladesh, which was pioneered by the Nobel Laureate for Peace, Dr. Mohammed Yunus, Professor of Economics in Chitagaon University of Bangladesh. $\mathrm{He}$ is also known as the Father of Self Help Groups. Microfinance initiatives have played a major role in making credit accessible to the unbanked rural women thereby bringing them within the Self Help Group-Bank Linkage Programme (SHG-BLP) fold on a continuous basis and contributing to a reduction in the gender gap in access to financial services (Khemnar, 2019). About 10 to 20 women of homogenous character are encouraged to form into group with financial commitment and mutual help. Regular thrift is emphasised by group members(Annapurna, 2017). Linking a designated bank branch to the Self Help Group (SHG) is referred to as SHG-Bank Linkage Programme (BLP)(Kulkarni, Pinto, Shetty, \& Mirzakhanyan, 2017). On such approach of microfinance which gained immense popularity in India is Self Help Group-Bank Linkage Programme (SHG-BLP), an initiative by NABARD. Microfinance has made tremendous strides in India over the years and it has become a household name in view of the multi-pronged benefits from microfinance services to the poor in our country. Microfinance has been tipped as a powerful tool to promote inclusive economic growth by financing and fostering development and bringing about positive socio-economic changes(Batra, 2018) .Microfinance through self help groups (SHG) has been recognised internationally as the modern means to combat poverty and rural unemployment, especially among women. It has been accepted that microfinance plays a vital role in reducing poverty since it paves the way for employment which leads to economic development(Lavoori \& Paramanik, 2014). Microfinance initiatives like the Self Help Bank Linkage Program (SH-BLP) has been increasingly promoted SHGs for their positive economic impact and to achieve women empowerment. Microfinance 


\section{International Journal of Social Science and Economic Research}

ISSN: $2455-8834$

Volume:06, Issue:07 "July 2021"

initiatives enable women to challenge the existing societal outdated norms and to promote their financial wellbeing. The most distinctive characteristic of microfinance programme is that it focuses on women financial development and empowerment(Kumari, 2014).

\subsection{Self Help Group- Bank Linkage Programme}

Even after the nationalization of the Banks in the nation, access to credit remained dreams of many. Till late nineties, concept of financial inclusion in the nation seemed to be vague and dissatisfactory. It was NABARD which came up with Self Help Group- Bank Linkage Programme (SHG-BLP) in 1992 based on its performance of pilot project launched by it in partnership with a NGO, MYRADA (Mysore Resettlement and Area Development Agency) in 1987. As such to overcome the credit gap created by the formal financial institutions, SHG-BLP programme by launched. Initially starting with financing 500 SHGs in the nation it has come a long way. According to NABARD Report on Status of Microfinance in India 2018-19 as far as 12.70 lakh SHGs with total saving amount being Rs.3732.36 crore as on March 2019. During the year the banks have disbursed loans of R58317.63 crore recording an increase of R 11131.75 crore over the last year. The total loan outstanding of SHGs also increased by $15.21 \%$ and stood at R87098.15 crore as on March 2019 as against R75598.45 crore in the previous year. The gross NPAs of the bank loans to SHGs declined from $6.12 \%$ as on 31 March 2018 to $5.19 \%$ as on 31 March 2019 and absolute amount of NPAs declined, implying actual reduction in NPAs (Status of Microfinance in India 2018-19). Self Help Groups thus being voluntary associations of the people, inculcate the value of savings, this empowers the members to use their collective power to earn themselves a decent amount of income and to come out of the vicious circle of the poverty. Self-help group-Bank linkage program is a major plank of the strategy for delivering financial services to the lower lungs of the society by linking them to formal banking sector. Self Help Group is the voluntary association of 10 to 20 individuals of small and low income group from same social and economic background(Randhawa \& Kaur, 2020). Due to widespread rural bank branch network, the SHG-BLM is very suitable to the Indian context. The programme uses SHGs as an intermediation between the banks and the rural poor to help in reducing transaction costs for both the banks and the rural clients(Harika \& Ramakrishna, 2017). Successful SHG can give guidance on financial matters like credit usage, repayment etc., to other SHGs with the support of NGOs or Government who have promoted/monitoring those groups( Kartigeyini \&Thavaraj, 2017).

\section{Objective}

1. To analyse the spread of Self Help Groups bank linkage programme in all the regions of India.

\section{Hypotheses}




\section{International Journal of Social Science and Economic Research}

ISSN: $2455-8834$

Volume:06, Issue:07 "July 2021"
a) The average amount of saving is same across the regions.
b) The average amount of loan disbursed is the same across the regions.
c) The average amount of loan outstanding is the same across the regions.

\section{Methodology}

The present study is based on the secondary data collected mainly from the NABARD's Report "Status of Microfinance in India." The time period for this study is eleven years from 2010-11 to 2020-21. For the selected data, to reflect the overall growth in the different regions of the country Mean, Standard Deviation (SD), Coefficient of Variation (CV) and Compound Annual Growth Rate (CAGR) is calculated. Later on Analysis of Variance (ANOVA) has been used in order to asses for statistical significance of variations across selected regions of the state.

\section{Findings and Discussions}

\subsection{Total microfinance savings with Banks for the study period:}

Table 1 throws light on the total microfinance savings with banks for a period of eleven years starting from 2010-11 to 2020-21. The table takes into consideration both the physical numbers of Self Help Groups as well as the savings amount in monetary terms. As observed by the calculated CAGR, it can be inferred that the overall growth in the number of SHGs for nine years is 4.57 per cent for Northern region, 6.26 per cent for North Eastern region, 6.71 per cent for Eastern region, 5.00 per cent for Central region, 4.44 per cent for the Western region and 1.16 per cent for the southern regions and 3.78 per cent in total. Further it can be concluded that the Eastern region with a growth of 6.71 per cent for eleven years has out shined the other regions of the country as far as the growth is concerned, it is followed by the North Eastern region. Further the Southern region recorded the lowest growth of mere 1.16 per cent which is less than the national aggregate. The second part of the table takes into consideration the microfinance savings linked in monetary terms which shows that the Southern region records a maximum growth of 17.20 per cent followed by Eastern region having growth of 16.76 per cent. The growth rate for the country as a whole is 16.45 per cent for study period. It can thus be inferred that for southern region, despite having less growth rate in the number of SHGs, its performance in monetary terms is quite impressive.

The difference in growth rates can be clearly seen by calculating the CAGr in table 1, but in order to see whether this difference is statistically significant or not, Analysis of variance (ANOVA) is used. Observing the ANOVA results in Table 1.A, the F-value is considered, since the calculated $\mathrm{F}$ value is significant at $1 \%$, we reject the both the hypothesis for the number of 


\section{International Journal of Social Science and Economic Research}

ISSN: $2455-8834$

Volume:06, Issue:07 "July 2021"

groups as well as for the saving amount of these groups. Thus concluding that all the regions performed differently, as far as microfinance savings with banks is concerned.

Table 1:Progress under Microfinance Savings of SHGs with Banks region wise during 2010-11 to 2020-21

\begin{tabular}{|c|c|c|c|c|c|c|c|c|}
\hline \multirow{16}{*}{$\begin{array}{l}\text { Number } \\
\text { of } \\
\text { SHGs }\end{array}$} & Year & Northern & Neastern & Eastern & Central & Western & Southern & Total \\
\hline & 2010-11 & 372772 & 324739 & 1527618 & 786436 & 960921 & 3489460 & 7461946 \\
\hline & 2011-12 & 409326 & 366718 & 1625714 & 812767 & 1062087 & 3683737 & 7960349 \\
\hline & 2012-13 & 372837 & 323896 & 1471099 & 702198 & 906016 & 3541505 & 7317551 \\
\hline & 2013-14 & 365208 & 316299 & 1468786 & 685929 & 896954 & 3696324 & 7429500 \\
\hline & 2014-15 & 360858 & 333981 & 1524614 & 817251 & 941144 & 3719621 & 7697469 \\
\hline & 2015-16 & 393475 & 429823 & 1700106 & 815653 & 1018049 & 3545896 & 7903002 \\
\hline & 2016-17 & 457199 & 452887 & 1953076 & 848514 & 1140601 & 2724598 & 8576875 \\
\hline & 2017-18 & 478883 & 485591 & 2130997 & 902222 & 1097448 & 3649296 & 8744437 \\
\hline & 2018-19 & 548624 & 523469 & 2654358 & 1062759 & 1388615 & 3836418 & 10014243 \\
\hline & 2019-20 & 577122 & 556899 & 2811130 & 1135083 & 1473853 & 3689236 & 10243323 \\
\hline & 2020-21 & 609808 & 633714 & 3122424 & 1345575 & 1550176 & 3961703 & 11223400 \\
\hline & mean & 449646.5 & 431637.8 & 1999084 & 901307.9 & 1130533 & 3594345 & 8597463 \\
\hline & S.D & 91768.02 & 108818.2 & 600532.5 & 200586.3 & 234246.1 & 318160.3 & 1327538 \\
\hline & C.V & 0.204089 & 0.252105 & 0.300404 & 0.22255 & 0.2072 & 0.088517 & 0.15441 \\
\hline & CAGr & 4.57 & 6.26 & 6.71 & 5.00 & 4.44 & 1.16 & 3.78 \\
\hline & Year & Northern & Neastern & Eastern & Central & Western & Southern & Total \\
\hline & 2010-11 & 32857 & 13104 & 140837 & 60338 & 82901 & 371592 & 701630 \\
\hline & 2011-12 & 25277 & 15252 & 94726 & 61358 & 87194 & 371335 & 655141 \\
\hline & 2012-13 & 29119 & 13011 & 139326 & 62422 & 69586 & 508263 & 821725 \\
\hline & 2013-14 & 28295 & 12882 & 152655 & 79056 & 92990 & 623862 & 989741 \\
\hline & 2014-15 & 23992 & 13022 & 215336 & 82370 & 109123 & 662141 & 1105984 \\
\hline & 2015-16 & 45014 & 19026 & 248352 & 84109 & 105704 & 866934 & 1369139 \\
\hline & 2016-17 & 49676 & 22955 & 336538 & 83898 & 138696 & 979657 & 1611422 \\
\hline & 2017-18 & 49293 & 32207 & 441803 & 95385 & 124694 & 1215826 & 1959211 \\
\hline & 2018-19 & 62452 & 40407 & 601154 & 133230 & 205275 & 1289928 & 2332448 \\
\hline & 2019-20 & 59550 & 48141 & 664333 & 171217 & 201880 & 1470085 & 2615206 \\
\hline & 2020-21 & 174345 & 83126 & 774912 & 211870 & 374023 & 2129485 & 3747761 \\
\hline & mean & 52715.45 & 28466.64 & 346361.1 & 102295.7 & 144733.3 & 953555.3 & 1628128 \\
\hline Amount & S.D & 42592.18 & 21867.15 & 239082.9 & 49390.25 & 88426.64 & 539379.1 & 963107.7 \\
\hline in Lakh & C.V & 0.807964 & 0.768168 & 0.690271 & 0.482818 & 0.610963 & 0.565651 & 0.591543 \\
\hline Rupees & CAGr & 16.38 & 18.28 & 16.76 & 12.09 & 14.67 & 17.20 & 16.45 \\
\hline
\end{tabular}


International Journal of Social Science and Economic Research

ISSN: 2455-8834

Volume:06, Issue:07 "July 2021"

Source: Status of Microfinance in India-various issues Nabard Mumbai

Table - 1(A): Hypothesis Testing- Savings of SHGs with Banks

\begin{tabular}{|l|l|l|}
\hline Variables & $\begin{array}{l}\text { Number of SHGs Linked with Saving } \\
\text { Amount }\end{array}$ & Saving Amount \\
\hline f-statistics & 282.5937 & 21.9195 \\
\hline p-value & 0.000 & 0.000 \\
\hline Inference & Rejected & Rejected \\
\hline
\end{tabular}

Source: Calculated (Table 1), Significant at $1 \%$ level

\subsection{Total Microfinance-Bank loan disbursed of SHGs for the study period:}

Table 2 shows the total loan disbursal of the Banks to the SHGs for a period of nine years, both in terms of number as well as in total loan amount. For this purpose, CAGr is calculated. The first part of the table considers the number of SHGs that have taken loan from banks, clearly it can be seen from the table that the Eastern region has witnessed the growth of 14.74 per cent which is more than the national average of 8.34 per cent or the study period. Part second of the table shows the progress in terms of amount of loan disbursal. Here also the Eastern region out passes the other regions with growth record of 22.33 per cent followed by southern region having growth of 11.89 per cent. As such the CAGr for the all the regions combined is 13.40 for the study period.

For observing the statistical significance of variations in loan disbursal to the different regions, we will make use of ANOVA. Table 2.A shows the result while F-value is interpreted, since the calculated $\mathrm{F}$ value is significant at $1 \%$, we reject both the hypothesis for the number of groups as well as for the amount of loan disbursal of these groups. Thus it can be concluded that all the regions performed differently. 
International Journal of Social Science and Economic Research

ISSN: 2455-8834

Volume:06, Issue:07 "July 2021"

Table2: Progress under Microfinance Banks loan disbursed region wise during 2010-11 to 2020-21

\begin{tabular}{|c|c|c|c|c|c|c|c|c|}
\hline \multirow{16}{*}{$\begin{array}{l}\text { Number } \\
\text { of } \\
\text { SHGs }\end{array}$} & Year & Northern & Neastern & Eastern & Central & Western & Southern & Total \\
\hline & 2010-11 & 42493 & 39307 & 247624 & 48734 & 91954 & 726022 & 1196134 \\
\hline & 2011-12 & 30751 & 51003 & 201201 & 58460 & 101044 & 705419 & 1147878 \\
\hline & 2012-13 & 31285 & 25168 & 182823 & 64180 & 70429 & 845936 & 1219821 \\
\hline & 2013-14 & 23918 & 16201 & 297478 & 66393 & 87846 & 874585 & 1366421 \\
\hline & 2014-15 & 43848 & 18791 & 351800 & 109231 & 97341 & 1005227 & 1626238 \\
\hline & 2015-16 & 38106 & 26037 & 412576 & 84282 & 112525 & 1158797 & 1832323 \\
\hline & 2016-17 & 46567 & 28961 & 497063 & 82012 & 106825 & 1136692 & 1898120 \\
\hline & 2017-18 & 51800 & 35017 & 720444 & 69295 & 128973 & 1255603 & 2261132 \\
\hline & 2018-19 & 55922 & 27086 & 909375 & 85135 & 146674 & 1474208 & 2698400 \\
\hline & 2019-20 & 62905 & 37807 & 1123517 & 111074 & 174218 & 1636481 & 3146002 \\
\hline & $2020-21$ & 67658 & 68116 & 1124578 & 128617 & 161159 & 1337266 & 2887394 \\
\hline & mean & 45023 & 33954 & 551679.9 & 82492.09 & 116271.6 & 1105112 & 1934533 \\
\hline & S.D & 13757.47 & 15031.3 & 359149.2 & 24810.58 & 32638.51 & 305411.7 & 719041.2 \\
\hline & C.V & 0.305565 & 0.442696 & 0.65101 & 0.300763 & 0.280709 & 0.276363 & 0.371687 \\
\hline & CAGr & 4.31 & 5.12 & 14.74 & 9.22 & 5.23 & 5.70 & 8.34 \\
\hline \multirow{16}{*}{$\begin{array}{l}\text { Amount } \\
\text { in Lakh } \\
\text { Rupees }\end{array}$} & Year & Northern & Neastern & Eastern & Central & Western & Southern & Total \\
\hline & 2010-11 & 37752 & 32096 & 161950 & 60755 & 62591 & 1099629 & 1454773 \\
\hline & 2011-12 & 33543 & 45129 & 162406 & 70937 & 75286 & 1266176 & 1653476 \\
\hline & 2012-13 & 34230 & 18022 & 129019 & 69889 & 70994 & 1736383 & 2058536 \\
\hline & 2013-14 & 28048 & 12819 & 151067 & 61806 & 86444 & 2061550 & 2401736 \\
\hline & 2014-15 & 42873 & 15795 & 329602 & 110909 & 117080 & 2141972 & 2758231 \\
\hline & 2015-16 & 48298 & 21969 & 349498 & 119067 & 188632 & 3001235 & 3728690 \\
\hline & 2016-17 & 57414 & 28421 & 473172 & 67958 & 148819 & 3102332 & 3878116 \\
\hline & 2017-18 & 54038 & 35721 & 908950 & 55943 & 155099 & 3508834 & 4718587 \\
\hline & 2018-19 & 62664 & 29001 & 1197079 & 72199 & 184565 & 4286256 & 5831763 \\
\hline & 2019-20 & 84694 & 57893 & 1785075 & 104249 & 249327 & 5484696 & 7765935 \\
\hline & $2020-21$ & 94658 & 68116 & 1487551 & 105428 & 230331 & 3786063 & 5807068 \\
\hline & mean & 52564.73 & 33180.18 & 648669.9 & 81740 & 142651.6 & 2861375 & 3823356 \\
\hline & S.D & 21359.83 & 17589.88 & 598058.4 & 23137.11 & 65595.01 & 1354077 & 2022740 \\
\hline & C.V & 0.406353 & 0.530132 & 0.921976 & 0.283057 & 0.459827 & 0.473226 & 0.529048 \\
\hline & CAGr & 8.71 & 7.08 & 22.33 & 5.13 & 12.57 & 11.89 & 13.40 \\
\hline
\end{tabular}

Source: Status of Microfinance in India-various issues Nabard Mumbai 
International Journal of Social Science and Economic Research

ISSN: 2455-8834

Volume:06, Issue:07 "July 2021"

Table - 2(A): Hypothesis Testing- Savings of SHGs with Banks

\begin{tabular}{|l|l|l|}
\hline Variables & $\begin{array}{l}\text { Number of SHGs Linked with Saving } \\
\text { Amount }\end{array}$ & Saving Amount \\
\hline f-statistics & 54.5789 & 30.4307 \\
\hline p-value & 0.000 & 0.000 \\
\hline Inference & Rejected & Rejected \\
\hline
\end{tabular}

Source: Calculated (Table -2).

Note: * significant at $1 \%$ level.

\subsection{Microfinance Outstanding of SHGs for the study period:}

Table 3 shows the loan outstanding for the different regions for the period of eleven years that is from 2010-11 to 2020-21. As such it can be observed from the table that as far as the number of SHGs is concerned, the loan outstanding amount has decreased for Northern region, Western region and the southern region with negative CAGr. As such there is a positive CAGr for the nation as a whole i.e.1.72 per cent. Further a positive CAGr is seen in case of amount of loan outstanding is concerned. With CAGr being 17.99 for eastern region which is greater than the national average i.e. 11.49 per cent.

For studying the statistical significance of difference in progress under microfinance-bank loan outstanding for different region, we will make use of ANOVA. Table 3. A shows the result while taking into consideration the hypothesis that the average amount of loan outstanding is the same across the regions. For the analysis part the F-value is interpreted, since the calculated $\mathrm{F}$ value is significant at $1 \%$, we reject both the hypothesis for the number of groups as well as for the amount of loan outstanding of these groups. Thus it can be concluded that all the regions performed differently.

Table-3: Progress under Microfinance Banks loan outstanding region wise during 2010-11 to 2020-21

\begin{tabular}{|c|c|c|c|c|c|c|c|c|}
\hline \multirow{7}{*}{$\begin{array}{l}\text { Numb } \\
\text { er } \\
\text { of } \\
\text { SHGs }\end{array}$} & Year & Northern & Neastern & Eastern & Central & Western & Southern & Total \\
\hline & 2010-11 & 149108 & 150021 & 1105533 & 358872 & 316821 & 2706408 & 4786763 \\
\hline & 2011-12 & 212041 & 159416 & 985329 & 352472 & 289472 & 2355732 & 4354442 \\
\hline & 2012-13 & 213955 & 143660 & 1020656 & 362521 & 295451 & 2415191 & 4451434 \\
\hline & 2013-14 & 183929 & 124569 & 978960 & 419834 & 269008 & 2221038 & 4197338 \\
\hline & 2014-15 & 176904 & 123041 & 1069329 & 438216 & 270718 & 2389972 & 4468180 \\
\hline & 2015-16 & 154724 & 150860 & 1130902 & 434797 & 258119 & 2543219 & 4672621 \\
\hline
\end{tabular}




\section{International Journal of Social Science and Economic Research}

ISSN: $2455-8834$

Volume:06, Issue:07 "July 2021"

\begin{tabular}{|c|c|c|c|c|c|c|c|c|}
\hline & 2016-17 & 143905 & 143222 & 1343296 & 398411 & 278097 & 2541356 & 4848287 \\
\hline & 2017-18 & 144428 & 143648 & 1412153 & 404378 & 276336 & 2639415 & 5020358 \\
\hline & 2018-19 & 124130 & 123554 & 1690515 & 324142 & 276901 & 2538090 & 5077332 \\
\hline & 2019-20 & 133515 & 131006 & 1955112 & 354466 & 284109 & 2818863 & 5677071 \\
\hline & 2020-21 & 143275 & 164421 & 2252039 & 368271 & 312913 & 2539325 & 5780244 \\
\hline & mean & 161810.4 & 141583.5 & 1358529 & 383307.3 & 284358.6 & 2518964 & 4848552 \\
\hline & S.D & 30590.1 & 14416.37 & 431805.6 & 37697.3 & 18132.35 & 168601.8 & 513977.7 \\
\hline & C.V & 0.189049 & 0.101822 & 0.317848 & 0.098347 & 0.063766 & 0.066933 & 0.106006 \\
\hline & CAGr & -0.362 & 0.83 & 6.68 & 0.23 & -0.113 & -0.578 & 1.72 \\
\hline \multirow{16}{*}{$\begin{array}{l}\text { Amou } \\
\text { nt in } \\
\text { Lakh } \\
\text { Rupee } \\
\text { s }\end{array}$} & Year & Northern & Neastern & Eastern & Central & Western & Southern & Total \\
\hline & 2010-11 & 90314 & 69525 & 420255 & 236540 & 124623 & 2180859 & 3122117 \\
\hline & 2011-12 & 117828 & 99327 & 462980 & 278029 & 136378 & 2539459 & 3634000 \\
\hline & 2012-13 & 116068 & 79676 & 553813 & 277685 & 146752 & 2763536 & 3937530 \\
\hline & 2013-14 & 110064 & 75380 & 494463 & 269666 & 164046 & 3179133 & 4292752 \\
\hline & 2014-15 & 153970 & 72209 & 617046 & 248614 & 198739 & 3863968 & 5154546 \\
\hline & 2015-16 & 115907 & 88473 & 703767 & 289590 & 203462 & 4310725 & 5711923 \\
\hline & 2016-17 & 91167 & 83160 & 888561 & 221368 & 208907 & 4664964 & 61581306 \\
\hline & 2017-18 & 86865 & 89048 & 1168064 & 216172 & 237207 & 5762489 & 7559845 \\
\hline & 2018-19 & 99374 & 83132 & 1652544 & 200443 & 246800 & 6427521 & 8709815 \\
\hline & 2019-20 & 122215.52 & 103194.55 & 2276461.39 & 225097.11 & 303111.2 & 7777427 & 1080750 \\
\hline & 2020-21 & 123034.12 & 144455.48 & 2594652.0 & 252282.02 & 328785.5 & 6885762 & 10328971 \\
\hline & mean & 111527.8764 & 89780.003 & 1075691.04 & 246862.3 & 208982.8 & 4577804 & 1046486 \\
\hline & S.D & 19365.29159 & 20926.595 & 767416.3 & 29370.71 & 66223.13 & 1900677 & 1715971 \\
\hline & C.V & 0.173636334 & 0.2330875 & 0.713416 & 0.118976 & 0.316883 & 0.415194 & 1.639745 \\
\hline & CAGr & 2.85 & 6.87 & 17.99 & 0.58 & 9.21 & 11.01 & 11.49 \\
\hline
\end{tabular}

Source: Status of Microfinance in India-various issues Nabard Mumbai 
International Journal of Social Science and Economic Research

ISSN: 2455-8834

Volume:06, Issue:07 "July 2021"

Table - 3(A): Hypothesis Testing- Savings of SHGs with Banks

\begin{tabular}{|l|l|l|}
\hline Variables & $\begin{array}{l}\text { Number of SHGs Linked with Saving } \\
\text { Amount }\end{array}$ & Saving Amount \\
\hline f-statistics & 493.6786 & 3.93380 \\
\hline p-value & 0.000 & 0.000 \\
\hline Inference & Rejected & Rejected \\
\hline
\end{tabular}

Source: Table -3.

Note: * significant at $1 \%$ level.

\section{Conclusion}

Since the beginning of the planning era, removal of disparities in the nation has been the key goal of the policy makers. These disparities existed not only in the form of income inequalities but also on the regional front. As such government has always made removing regional disparities as their top priority in the planning era so that all the regions grow and prosper equally thus making the nation developed through a balanced regional growth. The research paper observes that the SHGs-BLP played their role in achieving the target of banking with poor by overcoming the issues related to access to credit by showing a positive trend in the outreach of this programme which can be accessed for the savings, loan disbursal as well as for the loan outstanding amount. As such it can be concluded that as far as the savings linked SHGs and amount is concerned, the growth sows a positive trend for a period of eleven years. As the growth rate for the number of SHG is less in comparison to the growth seen in the monetary terms. Further as far as loan disbursal to SHGs in different regions is concerned, there is a positive trend in growth rate for the study period both in physical numbers as well as in the monetary terms. Lastly as far as the loan amount outstanding is observed, the nation wise growth rate shows a positive trend both for the number of SHGs as well as for the amount of loan outstanding. Different regions have performed different in all the three aspects. Using ANOVA test it is thus concluded that some regions have outshined other regions in their performance. Thus, giving little impetus to the objective of balanced regional growth, thus with some region outshining the other in their progress as far as this programme is concerned. As such the Self Help Group- Bank Linkage Programme has becoming a shining star in the field of microfinance in providing solutions to various problems of the nation.

\section{References}

[1] Annapurna, A. A. (2017). SHG-Bank Linkage Programme : An Indian Perspective. IJESC, 7(4), 6296-6302. 
International Journal of Social Science and Economic Research

ISSN: 2455-8834

Volume:06, Issue:07 "July 2021"

[2] Batra, S. (2018). A Structural Equation Model of Women Empowerment Through Self-Help Groups in Rajasthan. Journal of Organisation and Human Behaviour, 7(2), 14-22. Retrieved from http://proxy.library.tamu.edu/login?url=https://search.proquest.com/docview/2138650426?a ccountid=7082\%0Ahttp://linkresolver.tamu.edu:9003/tamu?url_ver=Z39.882004\&rft_val_fmt=info:ofi/fmt:kev:mtx:journal\&genre=article\&sid=ProQ:ProQ\%3Aabiglo bal\&atitle $=\mathrm{A}+\mathrm{St}$

[3] Harika, K., \& Ramakrishna, R. (2017). Trends in Micro Finance with SHG-Bank Linkage Model ( SHG- BLM ) in India during 2010-11 to 2015-16. 22(11), 17-28. https://doi.org/10.9790/0837-2211101728

[4] Khemnar, J. . (2019). Double-Blind Peer Reviewed Refereed Open Access International Journal - Included in the International Serial Directories Indexed \& Listed at: Ulrich's Periodicals Directory O, U.S.A., Open J-Gat e as well as in Cabell's Directories of Publishing Opportuni. International Journal of Physical and Social Science, 9(11), 118125.

[5] Kulkarni, D. D., Pinto, P., Shetty, N., \& Mirzakhanyan, A. (2017). Financial Inclusion through SHG-BLP : A Case Study of SKDRDP and NGVCT in World Review of Business Research Financial Inclusion through SHG-BLP : A Case Study of SKDRDP and NGVCT in India Niranjan Shetty* and Prakash Pinto ** Field of Research: Banking. International Review of Research in Emerging Markets and the Global Economy, 5(April), 91-107.

[6] Kumari, J. K. (2014). Woman Empowerment through Entrepreneurship in Service Sector with Special Reference to SHGs in Tourism. Global Journal For Research Analysis, III(IX), 159-160. Retrieved from http://theglobaljournals.com/gra/file.php?val=September_2014_1410773806_58.pdf\$\#\#h ttp://theglobaljournals.com/gra/articles.php?val=MjM1NQ==\&b1=229\&k=58

[7] Lavoori, V., \& Paramanik, R. N. (2014). Microfinance impact on women's decision making: a case study of Andhra Pradesh. Journal of Global Entrepreneurship Research, 4(1), 1-13. https://doi.org/10.1186/s40497-014-0011-6

[8] M.V. Kartigeyini \& Dr. H. Samuel Thavaraj. (2017). ISSN (ONLINE): 2454-9762 ISSN (PRINT): 2454-9762 Available online at. International Journal of Advanced Research in Management, Architecture, Technology and Engineering, 3(4), 95-100.

[9] Meena, S. S., \& Prasad, H. (2021). An Evaluative Study of Performance of Self Help Groups in Tribal Sub Region of Rajasthan. International Journal of Current Microbiology and 
International Journal of Social Science and Economic Research

ISSN: 2455-8834

Volume:06, Issue:07 "July 2021"

Applied Sciences, 10(01), 2916-2933. https://doi.org/10.20546/ijcmas.2021.1001.338

[10] Randhawa, S. K., \& Kaur, T. (2020). A Study of Non Performing Assets of Loans Outstanding Under SHG-Bank Linkage Programme in India. Envision: Interational Journal of Commerce and Management, 5976, 50-57.

\section{Reports}

[1] Government of India (2013), Debt and Investment survey (2013), NSSO (70 ${ }^{\text {th }}$ Round), Government of India, New Delhi

[2] Government of India (2011), Census of India (2011), NSSO, Government of India, New Delhi.

[3] National Bank for Agriculture and Rural Development (NABARD).(2011-12). Status of Microfinance Programme in India 2011-12. Mumbai, India

[4] National Bank for Agriculture and Rural Development (NABARD). (2015-16). Status of Microfinance Programme in India 2015-16. Mumbai, India

[5] National Bank for Agriculture and Rural Development (NABARD). (2018-19). Status of Microfinance Programme in India 2018-19. Mumbai, India

[6] National Bank for Agriculture and Rural Development (NABARD). (2019-20). Status of Microfinance Programme in India 2018-19. Mumbai, India

[7] National Bank for Agriculture and Rural Development (NABARD). (2020-21). Status of Microfinance Programme in India 2018-19. Mumbai, India 